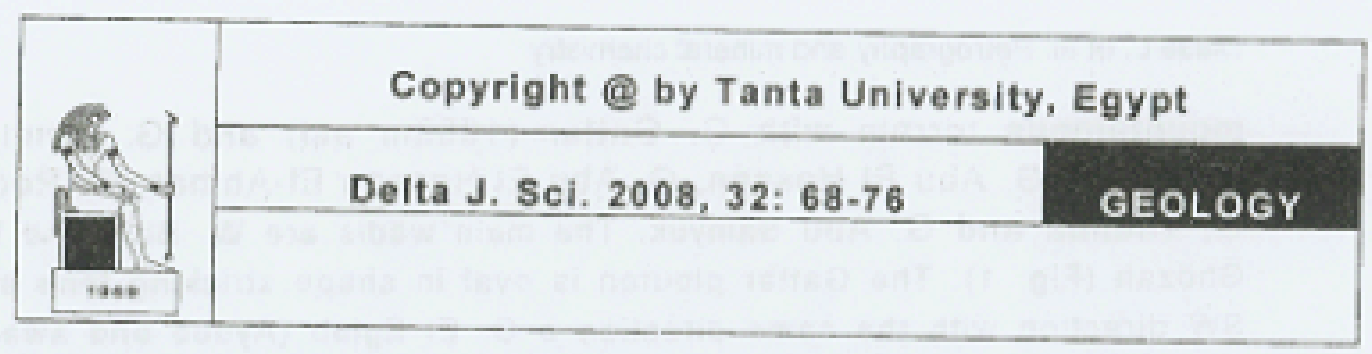

\title{
PETROGRAPHY AND MINERAL CHEMISTRY AT WADI BALLI AREA, CENTRAL EASTERN DESERT, EGYPT.
}

Emile L. lliase, Raafat M.S. Shahata, Kandil M. Kandil

and Joseph M. Samaan.

Nuclear Materials Authority P.O. Box 530, Maadi, Cairo, Egypt

(Received: 15 October 2008)

\begin{abstract}
The Gattar granites are composed mainly of quartz and feldspars as essential minerals and biotite hornblende, zircon, apatite and sphene as accessory minerals, some secondary minerals as epidote, chlorite and sericite are found. The Gattar granites originated from calc-alkaline magma and tectonically it is volcanic arc granites. The study includes some mineral as feldspars, biotite and, amphiboles from Wadi Balli under Environmental Scanning electron Microscopy (ESEM) attached by Energy Dispersive E-ray analyses (EDX) in nuclear Materials Authority (NMA), gave that the feldspars composed under temperature $850^{\circ} \mathrm{C}$ and biotite in Wadi Balli originated from magmatic origin.
\end{abstract}

\section{INTRODUCTION}

The Egyptian Eastern Desert, northern Sudan, western Saudi Arabia and Yemen have collectively been termed the Arabian Nubian Shield, which is characterized by four principal rock association: i.e. (1) an older shelf sequence of ortho- and paragnesis, (2) arc assemblages. (3) ophiolitic suits and (4) granitoid intrusive (Koener et al., 1987). The Egyptian granitoid rocks have been subdivided in different ways (Greenberg, 1981). They can be in general classified into two main types, the older and younger granites (El-Ramly and Akaad, 1960).

Gabal Gattar and Wadi Balli areas are part of the Northern Easter Desert (NED), of Egypt. They are cover by Pan-African basement rocks. Salman et al, (1990 \& 1991), Sayyah and Attawiya (1990). Shalaby (1990, 1995 and 1996) and Mahmoud (1995) meotioned that the granites of Gabal Gattar are calc alkaline granites and tectonically volcanic arc type.

The present study deals with the geology of Gabal Gattar granitic rocks and mineral chemistry of the granite at Wadi Balli by using (ESEM attached by (EDX)).

\section{General geology}

Gabal Gattar and Wadi Balli areas are located in the (NED) of Egypt between latitudes $26^{\circ} 521$ to $27^{\circ} 081 \mathrm{~N}$ and longitudes $33^{\circ} 131$ to $33^{\circ}$ $261 \mathrm{E}$ (Fig. 1). It comprises the Gattar granite pluton which forms a 
Liase L. et al. Petrography and mineral chemistry

mountainous terrain with G. Gattar (1963m asl) and G. Umm Disi $(1556 \mathrm{~m})$, G. Abu El Hassan, G. Abu El Hassan El-Ahmar, G. Reddah, G. Theima and G. Abu Samyuk. The main wadis are W. Balli and W. E Ghozah (Fig. 1). The Gattar plouton is oval in shape stricking lone at NESW direction with the same direction 0 G. El Eglab (Ayoub and awadalla, 2008), and G. Uqab EI Nugum south Eastern Desert Egypt (Samaan, 2000). G. Gattar covers an area of about $455 \mathrm{~km} 2$ with about $30 \mathrm{~km}$ length and $20 \mathrm{~km}$ wide. It is dissected by various faults trending mainly ENE-WSW, NNW-SSE, NW-SE and NNE-SSW (EI Rakaiby and Shalaby, 1992). The basement rocks in the studied area are classified according to Takla classification (2002), into

\section{Inter plate Magmatism and sediments}

Felsic and mafic dykes

Younger granites (G. Gattar granites)

Hammamat sediments

\section{Subduction-related granitoids (Arc granites)}

Diorites and granodiorites

\section{Arc metavolcanics}

\section{Metavolcanics}

Gabal Gattar granites are light pink in color, hard, holocrystalline and cars grained. Microscopically, it is composed mainly of quartz, potash feldspars and plagioclase as essential minerals, biotite, hornblende, zircon, apatite, opaqus and sphene as accessory minerals, epidote, chlorite and sericite are secondary minerals (lliase, 2003).

Quartz occurs as the predominant minerals constituting about $40 \%$ of the rock. It forms coarse anhedral crystals, showing wavy extinction, and enclosing zircon, biotite, perthite, plagioclase and hornblende.

Feldspars occur as perthite and plagioclase, the perthite is more predominant than plagioclase. Orthoclase perthite build simply twinned, coarse, subhedral to anhedral crystal, partially altered to epidote. Some plagioclase crystals are zoned while other show saussuritization (epidote + sodic plagioclase) occur in more calcic in central part of the plagioclase crystals. The plagioclase crystals enclose zircon and apatite (lliase, 2003).

Biotite occurs as euhedral flaky crystals, pleochroic from dark brown to yellow, and partialiy altered to chlorite. Some biotite crystals enclosed zircon. 
Delta J. Sci. (Geo) 32: 68-76

Hornblende occurs as coarse prismatic crystals, green in color, pleochroic from dark green to light green. Some hornblende crystals enclose opaqus and zircon, patially altered to chlorite.

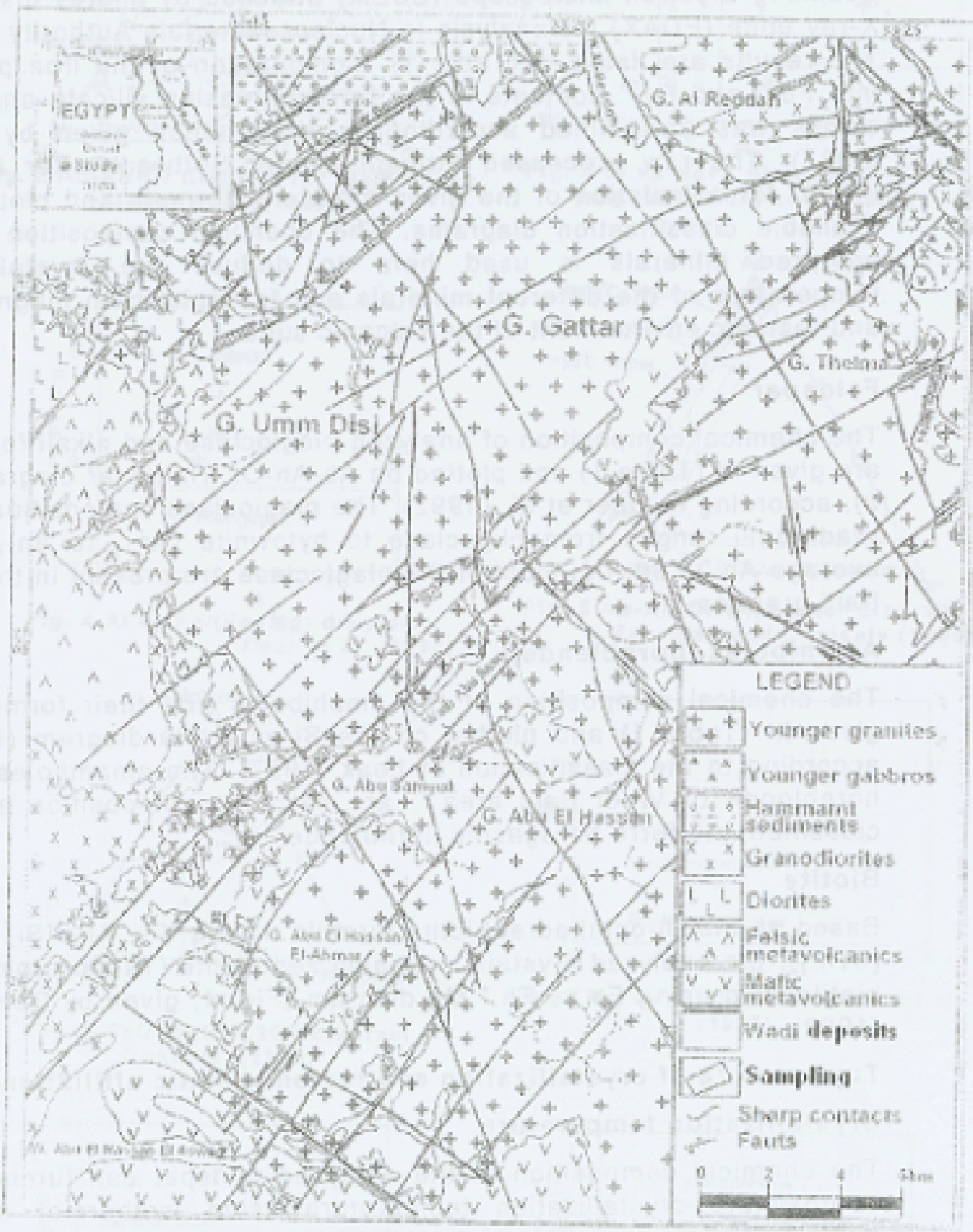

Fig. (1): Geological map of Gabal Gattar area Northern Eastern Desert, Egypt, showing the location map of the studied area at the top left side. (After El Rakaiby and Shalaby. 1992) 


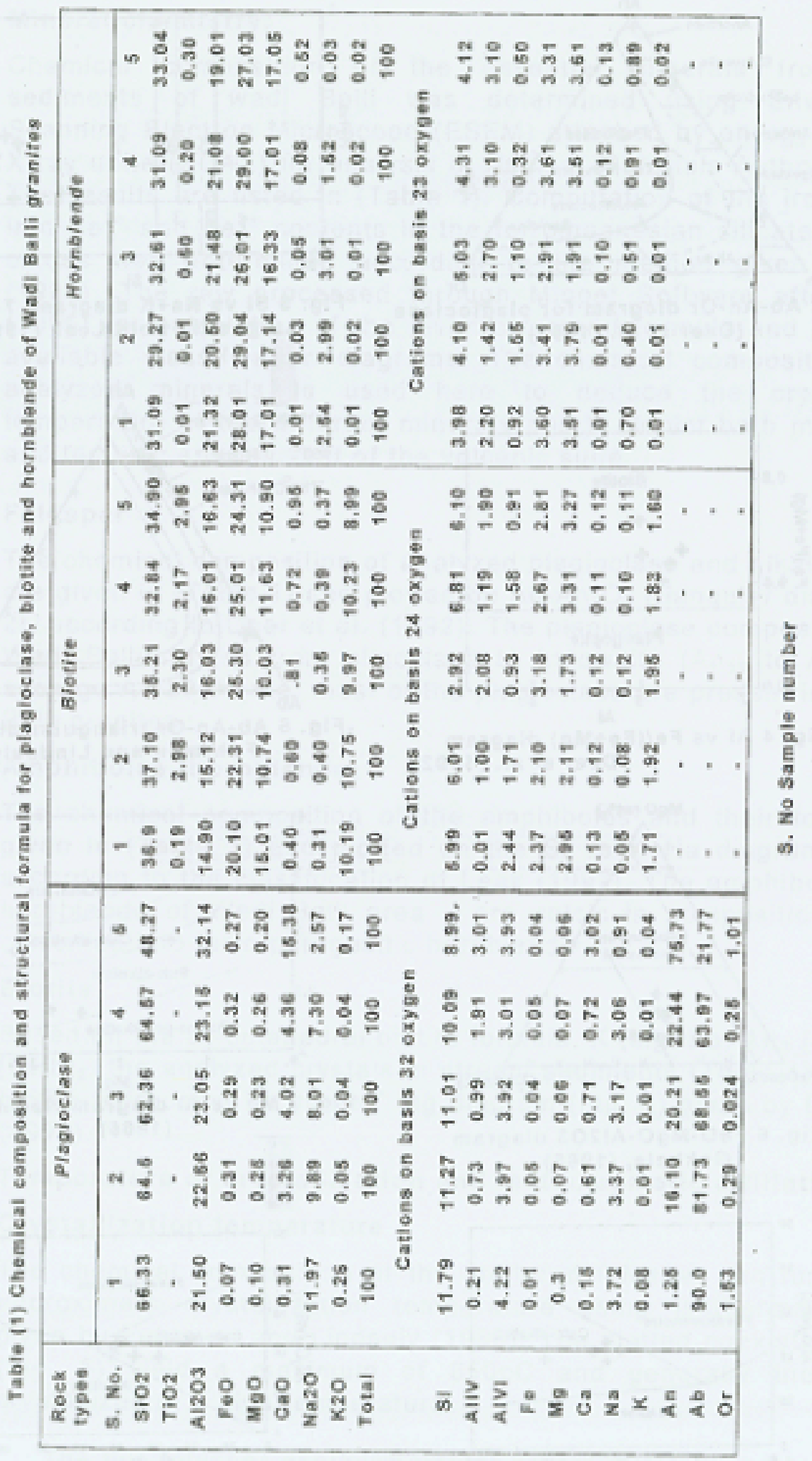




\section{Magma type and tectonic setting}

The ternary diagram $\mathrm{Fe}-\mathrm{Mg}-\mathrm{Al} 2 \mathrm{O} 3$ (Gokhale 1968), indicates that the biotite is of magmatic origin (Fig. 6). Nachit et al. (1985) used the biotite chemistry to discriminate between peraluminous, calc-alkaline. Subalkaline and alkaline-peralkaline granites. The analyzed biotite crystals from Wadi Balli granites plot a within sub-alkaline fieid except one sample plot in calc-alkaline field (Fig.7).

Abdel-Rahman (1994) used successfully the composition of igneous biotites in reflecting the nature of their host magmas. He defined three compositionally distinct fields: Biotite in alkaline anorogenic suites are mostly iron-rich siliceous annites ( $\mathrm{FeO} / \mathrm{MgO}=$ 7.40 ), biotites in peralumenous suites are siderophylliti in composition $(\mathrm{FeO} / \mathrm{MgO}=3.48)$, whereas those in calc-alkaline mostly subduction - related orogenic suites are moderately enriched in $\mathrm{MgO}$ with a $\mathrm{FeO} \% / \mathrm{MgO}$ ratio of 1.756 . The $\mathrm{FeO} \% / \mathrm{MgO}$ ratio of the analyzed biotite ranges between 1.36 and 2.20 with an average of 2.08. The obtained ratio is similar to calc-alkaline, subduction - related origin biotites. Moreover, the biotite of the calc-alkaline suites has the averages of $14.90 \%, 11.2 \%$ and $19.7 \%$ for their contents of $\mathrm{Al}_{2} \mathrm{O}_{3}, \mathrm{MgO}$ and $\mathrm{FeO}$ * respectively (Abdel - Rahman 1994).

The corresponding averages of the analyzed biotites are $15.99 \%$, $11.60 \%$ and $23.39 \%$ nearly the same as those of calc-alkaline suites. On the biotite discrimination diagrams given by the same author, namely $\mathrm{Al}_{2} \mathrm{O}_{3}$ vs. $\mathrm{MgO}$ and $\mathrm{FeO}^{*}$ (Figs. 8, 9) the studied biotites of Wadi Balli granites plot also in the field of calc-alkaline orogenic suites.

\section{Conclusion}

The Gabal Gattar area is bounded by latitudes $26052 /$ to $27008 / \mathrm{N}$ and longitudes $33013 /$ to $33026 / \mathrm{E}$. It comprises the Gattar batholith which is very rugged, where the highest peaks are displayed by the pink Gattarian granites namely G. Gattar $(1963 \mathrm{~m}$ asl) and G. Umm Disi $(1556 \mathrm{~m})$, G. Abu El Hassan, G. Abu El Hassan El-Ahmar, G. Reddah, G. Theima and G. Abu Samyuk. The main wadis 'are W. Balli and W. El Ghozah southerly.

The G. Gattar area covered with Precambrian basement rocks represented by metavolcanics, diorites, granodiorites, hammamat sediments and the younger Gattar granites pluton. It is dissected by various faults mainly trending in the ENE-WSW, NNW-SSE, NW-SE and NNE-SSW. 
Lliase L. et al. Petrography and mineral chemistry

Petrographicaly the studied Gattar granites are composite from quartz, perthite and plagioclase as essential minerals, together with biotite, hornblende, zircon, apatite, opaqus and sphene as accessory minerals, epidote, chlorite and sericite are secondary minerals. By study the different grains from the granites of Wadi Balli under the ESEM attached by EDX units found that, the plagioclase composition ranges from oligoclase (An10 to An76), and composite at temperature $850^{\circ} \mathrm{C}$. The amphiboles of Wadi Balli are calcic in composition and are classified into ferropargasitic hornblende. Finally the analyzed biotite crystals in Wadi Balli gave that the biotites are of magmatic originated from calc-alkaline magma.

\section{References}

Abdel - Rahman, A.M., (1994): Nature of biotites from alkaline calc-alkaline and peraluminous magmas. J. Petrol., 35: pp. 525-541

Ayoub, R.R. and Awadalla, G.Sh., (2008) radioactivity and geochemistry of jasperold veins in Gabal El Aglab granites, northefn eastern desert. Egypt. gth inter Con! on the Geol. Arab Worled, Cairo Univ. Abstract. P172.

Deer, W.A., Howle, R.A. and Zussman, J., (1992): An introduction to the rock forming minorals. 2th Edition, Longman Scientific and Technical, London, 696 p.

Droop, G.T.R., (1987): A general equation for estimating Fe3+ concentration in ferromagnesian silicates and oxides from microprope analyses. using stiochiometric criteria. Miner. Mag., 51: p9.431-435.

El-Rakaiby, M.L. and Shalaby, M.H., (1992): Geology of gabal Gattar batholith, centra! Eastern Desert, Egypt. Int. J. Remote Sensing, 13: pp $2337-2347$

El-Ramly M.F, and Akaad, M.K. (1960): The basement complex in the Central Eastern Desert of Egypt between lat. $24^{\circ} 30 /$ and $25^{\circ} 40 /$ E. Geoi. Surv. Egypt, P8, 15p.

Fuhrman, M.L. and Lindsley, D.H., (1938): Ternary feldspar modeling and thermometry. American Mineralogist, 73 ; pp. $201-215$

Gokhale, N.W., (1968): Chemical composition of biotite as guides to ascertion the origin of granite. Buli. Soc. Geol. Finla, 40: pp. 107-111.

Greenberg. J.K. (1981): Characteristic and origin of Egyptian Yonder Granites. Buil. Geol. Soc. Am 92, II, 749-840.

IIiase, E.L. (2003): Radiometric, petrochemical and gecmorphological studies of the area around Gabal Gattar, north Eastern Desert, Egypt. Ph.D. Thesis, Faculty of Science, Tanta Univ. 189 p.

Leak, B.E. (1997): Nomenciature of amphiboles. Am. Mineral. Mag., 63, 1023-1052.

Mahmoud, H.M.K., (1995) : Studies on the distribution and recovery of uraniummolybdenum from their minerals from G. Gattar area, Eastern Desert, Egypt.
M/Sc. Thesis. Cairo Univ. 133p.

Nachit, H., Razafim, N., Stuss, J.M. and Carron, J.P., (1985): Composition chimique des biotites et typologie magmatique des granitoides. Comptes Rendus Hebdomadaires de L" Academie des sciencas, 301(11): pp.813-818.

Richard, L.R., (1995): Mineralogical and petrological data processing system. Minpet Software (o) 1988-1995, version 2.02

Salman, A.B., El-Aassy, I.E, and Shalaby, M.H., (1990): New occurrence of uranium mineralization in Gabal Gattar, Northern Eastern Desert, Egypt. Annals Geol. Surv. Egypt, V.XVI, 89-101.

Salman, A.B., All, M.M. and Shaiaby, M.H., (1991): Stream sediments survey in Gabal Gattar-Umm Dissi granites, Northern Eastern Desert of Egypt. Internal report. 
Delta J. Sci. (Geo) 32: 68-76

Samaan, J.M. (2000) Geology, petrology and radioactivity of the basement rocks of Gobel Uqab El Nugum-Gebel Seiga area, south wadi Garara, South Eastern Desert Egypt. Ph. D. Thesis, Caire, Univ,, 247p

Sayyah, T.A, and Attawiya, M.Y., (1990): Contribution to the mineralogy of uranium occurrence of Gabsal Gattar granites, Eastern Desert, Egypt. Arab. J. Nucl. Sci. and Appl., Cairo Egypt. 23/1, 171-184.

Shalaby, M.H. (1990): uranium mineralization in Northern Gabal Gattar locality, Northern Eastern Desert. 7th Conf. Phanerozoic and Develop. Al Azhar Univ. Cairo.

Shalaby, M.H., (1995): New occurrence of uranium mineralization GVII, Gabal Gattar uranium prospect. Northern Eastern Desert, Egypt, Bull. Fac. Sci., Alex. Univ.
Cairo.

Takla, M. A. (2002) Classification and characterization of the shield rocks of Egypt 6th international conference on the Geology of Arab World, Cairo University.
Abstracts, p. xoxii.

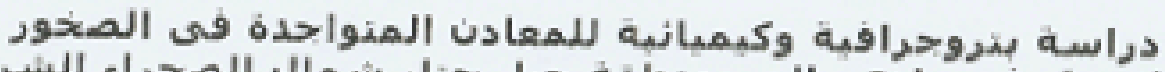

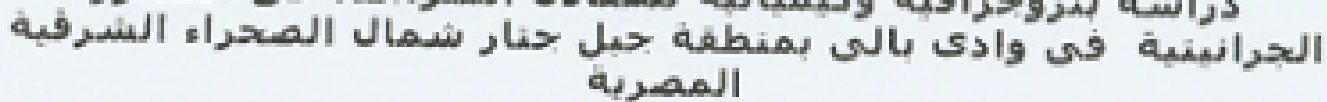

د, امبل لويس الباس و د. رافت منير صليب و د. قندبل مخمد قنديل و د>>وزيف مبحانبل سمعان

هيثة الواد النووية صندوف بريد 530 المعادى العاهرة

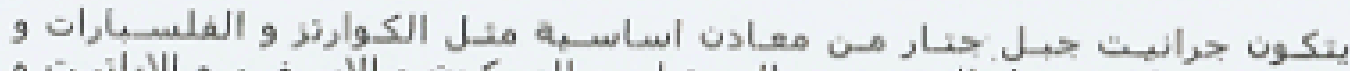

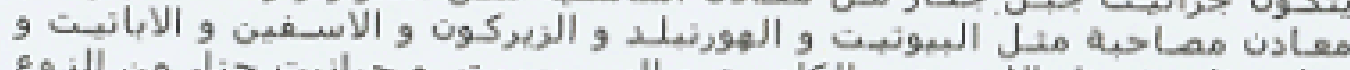

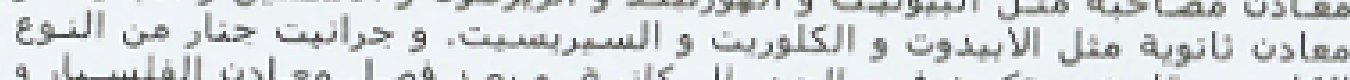

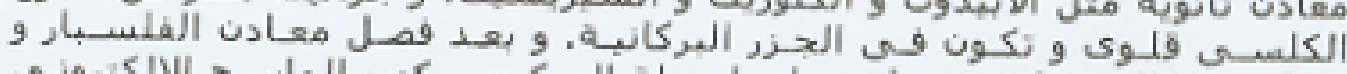

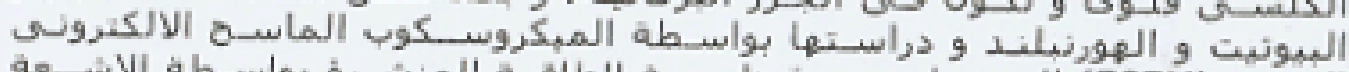

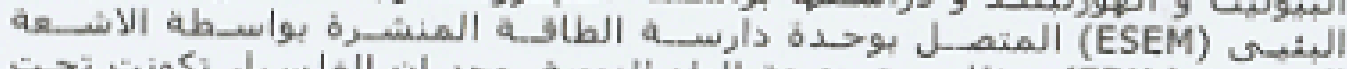

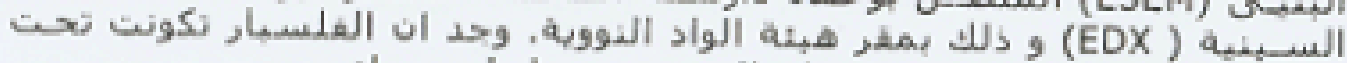

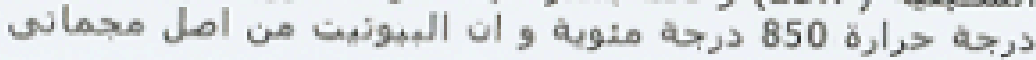

